\title{
Contrasting impacts of heat stress on violent and nonviolent robbery in Beijing, China
}

Article

Accepted Version

Hu, X., Chen, P., Huang, H., Sun, T. and Li, D. (2017)

Contrasting impacts of heat stress on violent and nonviolent robbery in Beijing, China. Natural Hazards, 87 (2). pp. 961972. ISSN 0921-030X doi: https://doi.org/10.1007/s11069-0172804-8 Available at https://centaur.reading.ac.uk/71096/

It is advisable to refer to the publisher's version if you intend to cite from the work. See Guidance on citing.

To link to this article DOI: http://dx.doi.org/10.1007/s11069-017-2804-8

Publisher: Springer

All outputs in CentAUR are protected by Intellectual Property Rights law, including copyright law. Copyright and IPR is retained by the creators or other copyright holders. Terms and conditions for use of this material are defined in the End User Agreement.

$\underline{\text { www.reading.ac.uk/centaur }}$ 
Central Archive at the University of Reading

Reading's research outputs online 


\title{
1 Contrasting impacts of heat stress on violent and non-violent robbery
}

\section{in Beijing, China}

\author{
Xiaofeng $\mathrm{Hu}^{1 *}$, Peng Chen ${ }^{1}$, Hong Huang ${ }^{2}$, Ting $\mathrm{Sun}^{3}$, Dan $\mathrm{Li}^{4}$
}

Abstract: Previous studies investigating the relation between heat stress and crime incidents often focus on violent crimes. In this study, the impacts of heat stress on two types of robbery (violent and non-violent) in China are compared using crime statistics collected in Beijing and heat stress indices that consider the combined effects of temperature and humidity. The results indicate that the abrupt change in the trend of robbery rates is affected by the 2008 Beijing Olympic Games. The non-violent robbery rates have a more pronounced seasonality and are better correlated with heat stress at daily scales, especially during the period from 2009 to 2014 when no trend exists. The results also demonstrate that both violent and non-violent robbery rates significantly increase with heat stress in spring. The non-violent robbery rates also significantly increase with heat stress in summer. The influence of heat stress on violent robbery rate is more complicated and non-linear.

Key words: violent, robbery, temperature, relative humidity, heat stress

\footnotetext{
${ }^{1}$ School of Information Technology, People's Public Security University of China, Beijing, China.

2 Institute of Public Safety Research, Tsinghua University, Beijing, China.

${ }^{3}$ Department of Hydraulic Engineering, Tsinghua University, Beijing, China.

${ }^{4}$ Department of Earth and Environment, Boston University, Boston, MA, USA.

* Corresponding author: xiaofenghu1986@gmail.com
} 


\section{Introduction}

The impact of heat stress on human conflicts has been widely acknowledged. Many studies argued that higher temperatures increased the risks of interpersonal violence and intergroup conflict (Barnett and Adger, 2007; Bernauer et al., 2012; Burke et al., 2009; Field, 1992; Gamble and Hess, 2012; Hsiang et al., 2013; Hsiang et al., 2011; Mares, 2013; O'Loughlin et al., 2012; Scheffran et al., 2012; Tol and Wagner, 2010; Zhang et al., 2011). In addition to human conflicts, studies also demonstrated a strong impact of heat stress on common crimes (Brunsdon et al., 2009; Chen et al., 2011; Horrocks and Menclova, 2011; Ranson, 2014).

Most previous studies (Field, 1992; Horrocks and Menclova, 2011; Jacob et al., 2006; Mares, 2013; Ranson, 2014) suggested that temperature had a significantly positive effect on violent crimes. For example, Jacob et al. (2006) pointed out that a $10^{\circ} \mathrm{F}$ increase in average weekly temperature was associated with a 5\% increase in violent crime. Mares (2013) showed an average $1 \%$ monthly increase in violent crimes for each degree increase in anomalous temperature. However, there seems no consensus regarding the impact of heat stress on property crimes. Field (1992) indicated that burglary, theft and robbery were all positively and significantly correlated with temperature, which was also supported by Chen et al. (2011). However, Cohn and Rotton (2000) showed that theft was negatively correlated with temperature while both burglary and robbery were positively correlated with temperature. Some studies suggested that property crimes may be affected by heat stress in more complicated ways. For example, Ranson (2014) demonstrated that the relationship between temperature and property crimes (such as burglary and larceny) was highly non-linear.

More importantly, few studies directly compared impacts of heat stress on violent and 
non-violent crimes, which motivates our study. In this study, we aim to investigate the contrasting impacts of heat stress on violent and non-violent crimes in China using robbery as an example. Previous studies (Horrocks and Menclova, 2011; Ranson, 2014) have pointed out that robbery was affected by heat stress factors (e.g., temperature), but those studies did not separate violent and non-violent robbery. The reason that robbery is selected is because China separates violent robbery from non-violent robbery, which is not always the case in western countries, thereby providing a good testbed for studying the contrasting impacts of heat stress on violent and non-violent crimes. The violent robbery refers to crimes to obtain properties by violence (Chen et al., 2011). The non-violent robbery is to obtain properties when someone is unaware first but instantly becomes aware of the conduct. This is different from stealing in the sense that stealing is conducted secretly throughout the conduct. As an example, if someone steals a necklace from a lady when the lady is unaware throughout the whole incident, it is stealing; if someone takes the necklace away from the lady's neck when she is unaware, but at the instant the lady realizes that someone is taking her necklace away but could not stop it, this is non-violent robbery; if someone obtains the necklace from the lady by violence, it is a violent robbery. Will both types of robbery be affected by heat stress in the same way? If not, what is the difference and why does the difference occur? These questions frame the scope of our study. 


\section{Data}

The analysis is based on a ten-year (from 2005 to 2014) data set of daily robbery numbers provided by Beijing Municipal Public Safety Bureau. Beijing is the capital of China, which has a monsoon-influenced, humid continental climate. More than 21.1 million people live in Beijing now. Between 2005 and 2014, more than 40 thousands robbery incidents were reported in Beijing.

To examine and compare the relation between the two types of robbery and heat stress in Beijing, four heat stress indices that combine temperature and relative humidity are used in this paper, including the Discomfort Index (DI), the simplified Wet Bulb Globe Temperature (sWBGT), the Humidex (HUMIDEX) and the Temperature Humidity Index for Comfort (THIC), as described in Table A1 of Appendix. Only the results with DI are discussed here since results with other heat stress indices are very similar (e.g., the results with sWBGT are shown in the Appendix). The DI was developed as a calibration index for air conditioners (Thom, 1959), which is defined based on the air temperature and the wet bulb temperature:

$$
\mathrm{DI}=0.5 T_{\mathrm{W}}+0.5 T_{\mathrm{C}}
$$

where $T_{\mathrm{c}}$ is the air temperature $\left({ }^{\circ} \mathrm{C}\right)$ and $T_{\mathrm{w}}$ is the wet bulb temperature $\left({ }^{\circ} \mathrm{C}\right)$ whose definition can be found in Appendix. The risk levels associated different heat stress values (Buzan et al., 2015) are shown in Table A2.

The heat stress indices are calculated based on the climate data downloaded from the website of rp5 (http://rp5.ru/), where the weather information comes from server of international data exchange, NOAA, the United States and the automated data transfer system (ADT) of Roshydromet. We select the daily weather data covering the same period as the crime data. The robbery rate is defined as the robbery incidents per 10 million $\left(10^{7}\right)$ people. Here we use "robbery 
rate" instead of "the number of robbery incidents" based on the assumption that a larger population lead to more crime incidents even under the same climatic conditions, thus normalizing the robbery incidents by the total population of Beijing avoids, to some extent, the influence of population increase in Beijing over the study period. To examine the relationship between the robbery rate and heat stress, we further divide the robbery rate (daily incidents $/ 10^{7}$ •people) into 11 bins (i.e., $0 \sim 1,1 \sim 2, \ldots, 9 \sim 10$ and $>10$ ) and then calculate the average heat stress in each bin. Then we use simple linear regression analysis to evaluate the relations between the two types of robbery and heat stress. Motivated by previous studies (Hsiang et al., 2013; Mehluma et al., 2006; Miguel, 2005), we also examine the relation between rainfall amounts and crime rates. However, we do not find clear relations between rainfall and the two types of robbery in Beijing. Since the focus of our study is on heat stress, the results about rainfall are not presented. 


\section{Results and discussions}

\subsection{Long-term trends}

To investigate the influence of heat stress on robbery, which occurs at daily scales and is influenced by weather variability, we need to first understand the long-term trends in robbery rates and their variations at longer, climate scales. Fig. 1 shows the temporal variations of temperature $\left({ }^{\circ} \mathrm{C}\right)$, relative humidity $(\%)$, violent and non-violent robbery rates (daily incidents $/ 10^{7} \cdot$ people) from 2005 to 2014 in Beijing. Here we aggregate all the data to monthly scales. It is clear that temperature and relative humidity $(\mathrm{RH})$ have distinct seasonal cycles, but there is no trend in temperature or RH or their diurnal ranges. The story about robbery rates is the opposite. Although seasonal variations seem to exist, they are not as strong as those of temperature or RH. But it is evident that before the summer of 2008 , decreasing trends are associated with both violent and non-violent robbery rates; while after 2008, these decreasing trends disappear. From 2005 to 2014, the gross domestic production (GDP) and population of Beijing increase continuously, thus neither of these two factors seems to be able to explain why the summer of 2008 is a turning point. The most likely reason is the 2008 summer Beijing Olympic Games. After winning the bid to host the 2008 Summer Olympics in 2001, the Beijing government initiated anti-crime campaigns and increased law enforcement forces, and as a result, the crime incidents number decreased gradually. It is clear that both violent and non-violent robbery rates were very low in the summer of 2008 and remained at a low level from 2008 to 2014. From Fig. 1 it can be concluded that the long-term trends of crime rates in Beijing are dominated by socio-economic reforms and changes that occur at longer time scales. 

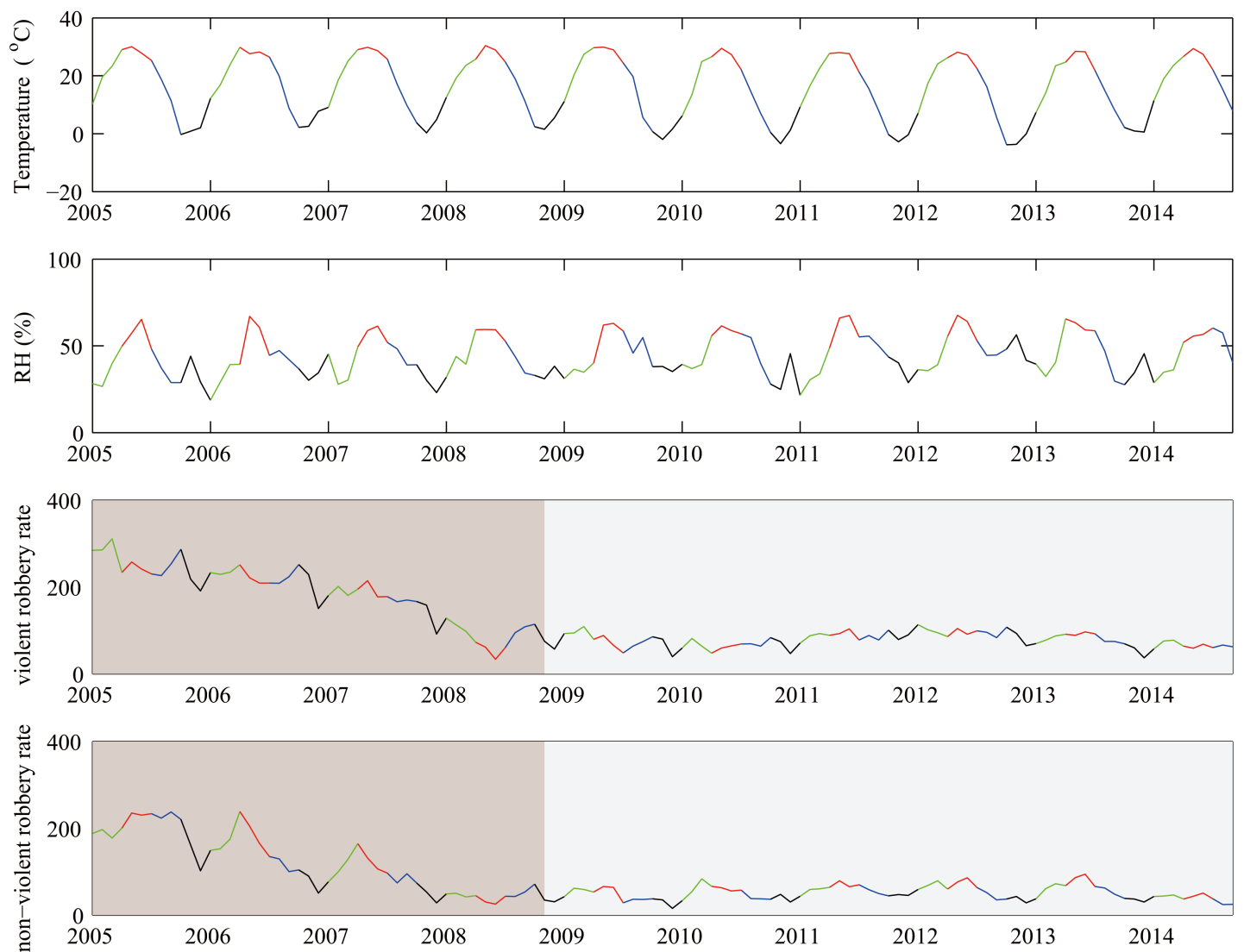

Fig. 1 Temporal variations of temperature $\left({ }^{\circ} \mathrm{C}\right)$, relative humidity $(\%)$, violent and non-violent robbery rates (daily
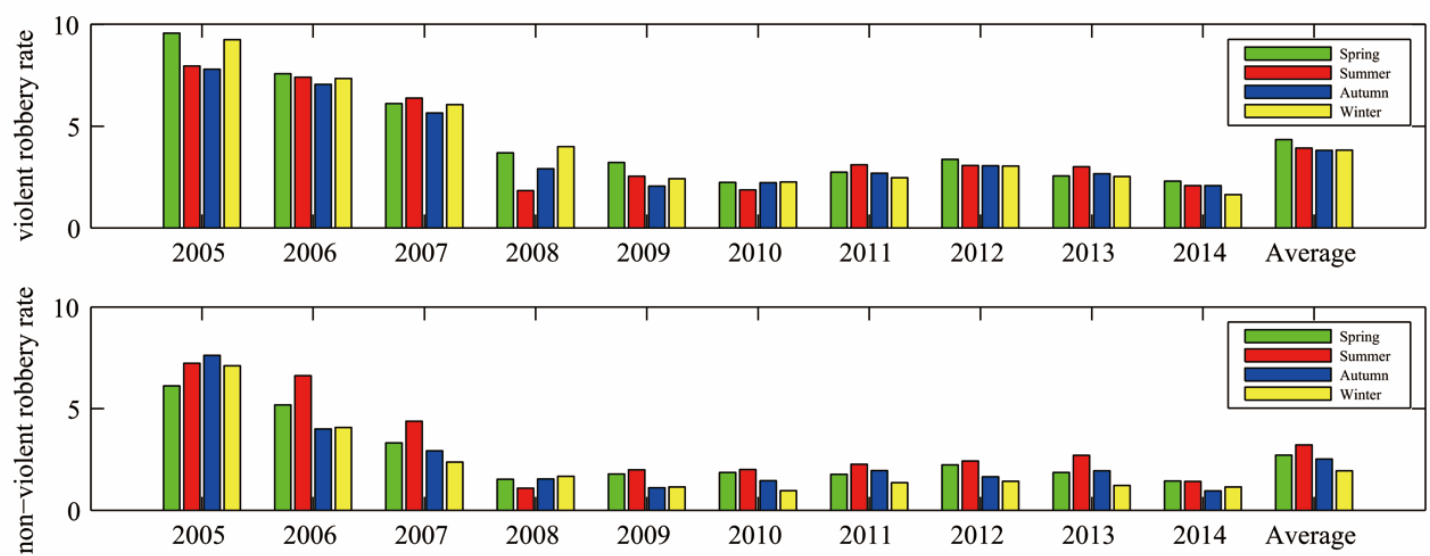

119 Fig. 2 Distribution of violent and non-violent robbery rates (daily incidents $/ 10^{7}$-people) in different seasons from 2005 to 2014 in Beijing. The green bar represents spring, the red bar represents summer, the blue bar represents 
Fig. 2 shows the distribution of violent and non-violent robbery rates (daily incidents $/ 10^{7}$ people) in different seasons from 2005 to 2014. As can be seen, the violent robbery rates in different seasons are very close across seasons (except in 2005 and 2008), and the average rates of the whole period are also similar in different seasons (with a slightly higher number in spring). The non-violent robbery rate is in general the highest in summer and lowest in winter, which seems to suggest that non-violent robbery has stronger seasonal variations than violent robbery. Close inspection of Fig.1 reveals that this is indeed the case. It is also clear that both violent and non-violent robbery rates in the summer of 2008 are much lower than their counterparts in other seasons of 2008 and other years. This is again because of the Beijing Olympic Games, which encouraged the Chinese government to improve the security level.

From the above analysis it can be seen that the two types of robbery are both significantly affected by the Beijing Olympic Games, and non-violent robbery shows a more pronounced seasonality than violent robbery. Given these findings, we divide the dataset into two periods: from 2005 to 2008 and from 2009 to 2014. For the first period, linear trends exist as described by the following equations:

$$
\begin{aligned}
& R=-0.0048 t+9.55, \text { for violent robbery with } \mathrm{R}^{2}=0.41^{*} \\
& R=-0.0048 t+7.41, \text { for non-violent robbery with } \mathrm{R}^{2}=0.45^{*}
\end{aligned}
$$

where $t$ represents the $t^{\text {th }}$ day, $R$ is the crime rate, and $*$ donates a significance level lower than 0.05. For the second period (from 2009 to 2014), no significant trend is detected. The linear trends again suggest that crime rates are strongly affected by socio-economic factors (beyond the total population) such as government regulations and increases in security level. More importantly, these trends suggest that socio-economic factors affect crime rates at long-term scales (e.g., larger 


\subsection{The influence of heat stress at daily scales}
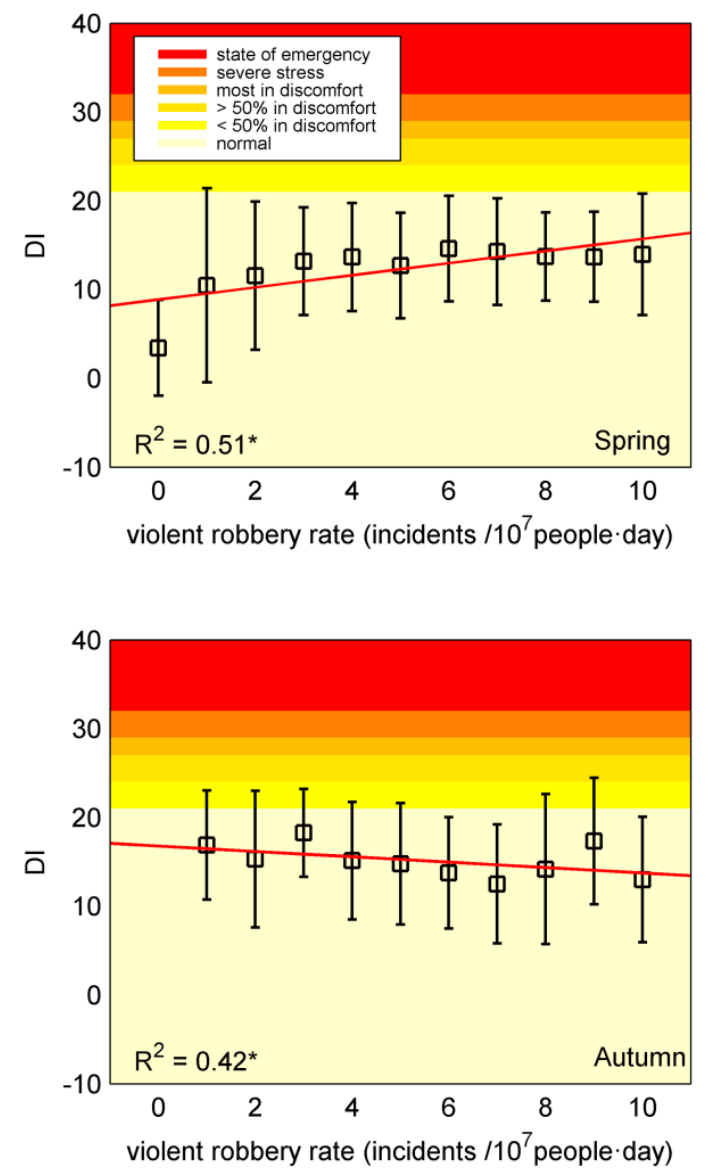
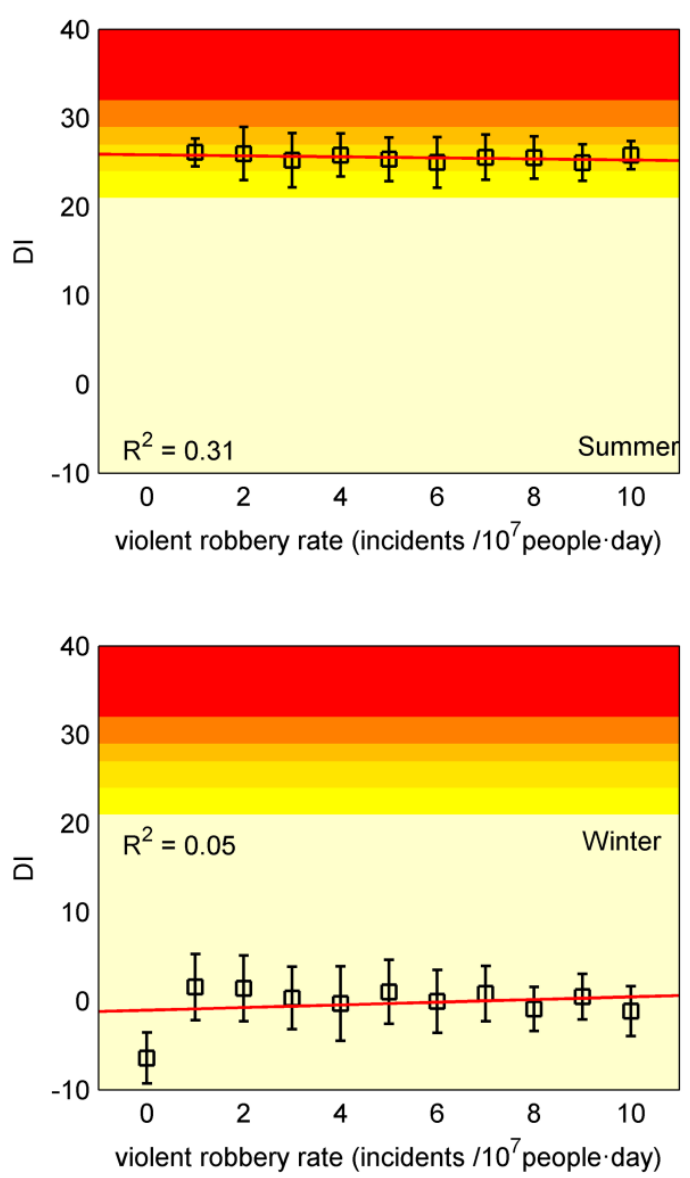

at daily scales. To do so, we separate the results in different seasons. This is because the relations between heat stress and robbery can be induced by correlations with both daily (meteorological) variations and seasonal (climate) variations. For example, students have long summer/winter vacation that increases the opportunity of interpersonal contact in cities like Beijing where the student population is large; people also tend to wear light cloths during summer, which could expose their valuable belongings and lead to robbery. For these reasons, crime incidence would be higher during summer. Our data indeed indicate that the relation between heat stress and crime rates is very strong when different seasons are not separated (not shown). This is, however, not related to how hot the summer is. To examine the influence of heat stress, it would be necessary to show that hot days in summer have higher incidence than cool days in summer, or that heat stress conducted separately for four seasons. the risk level of " $<50 \%$ in discomfort", " $>50 \%$ in discomfort" or "most in discomfort" in summer. The violent robbery rate increases with DI value in spring and winter, but decreases with DI value in summer and autumn. Simple regression analysis is also conducted to quantify the relation between violent robbery and DI, and the results are shown in Table1 (also shown in Fig. 3). The $\mathrm{R}^{2}$ values are larger than 0.4 and significant in spring and autumn, but are lower than 0.3 and not significant in summer and winter. 


\begin{tabular}{|c|c|c|c|c|}
\hline \multirow{2}{*}{ Season } & \multicolumn{2}{|c|}{ before 2009} & \multicolumn{2}{|c|}{ after 2009} \\
\hline & violent robbery & non-violent robbery & violent robbery & non-violent robbery \\
\hline Spring & $0.51 *(0 \sim 10)$ & $0.74 *(0 \sim 10)$ & $0.63 *(0 \sim 8)$ & $0.96 *(0 \sim 7)$ \\
\hline Summer & $0.31(0 \sim 10)$ & $0.40 *(0 \sim 10)$ & $0.30(0 \sim 9)$ & $0.89 *(0 \sim 7)$ \\
\hline Autumn & $0.42 *(0 \sim 10)$ & $0.20(0 \sim 10)$ & $0.01(0 \sim 8)$ & $0.69 *(0 \sim 6)$ \\
\hline Winter & $0.05(0 \sim 10)$ & $0.15(0 \sim 10)$ & $0.44(0 \sim 7)$ & $0.66(0 \sim 4)$ \\
\hline
\end{tabular}
data.
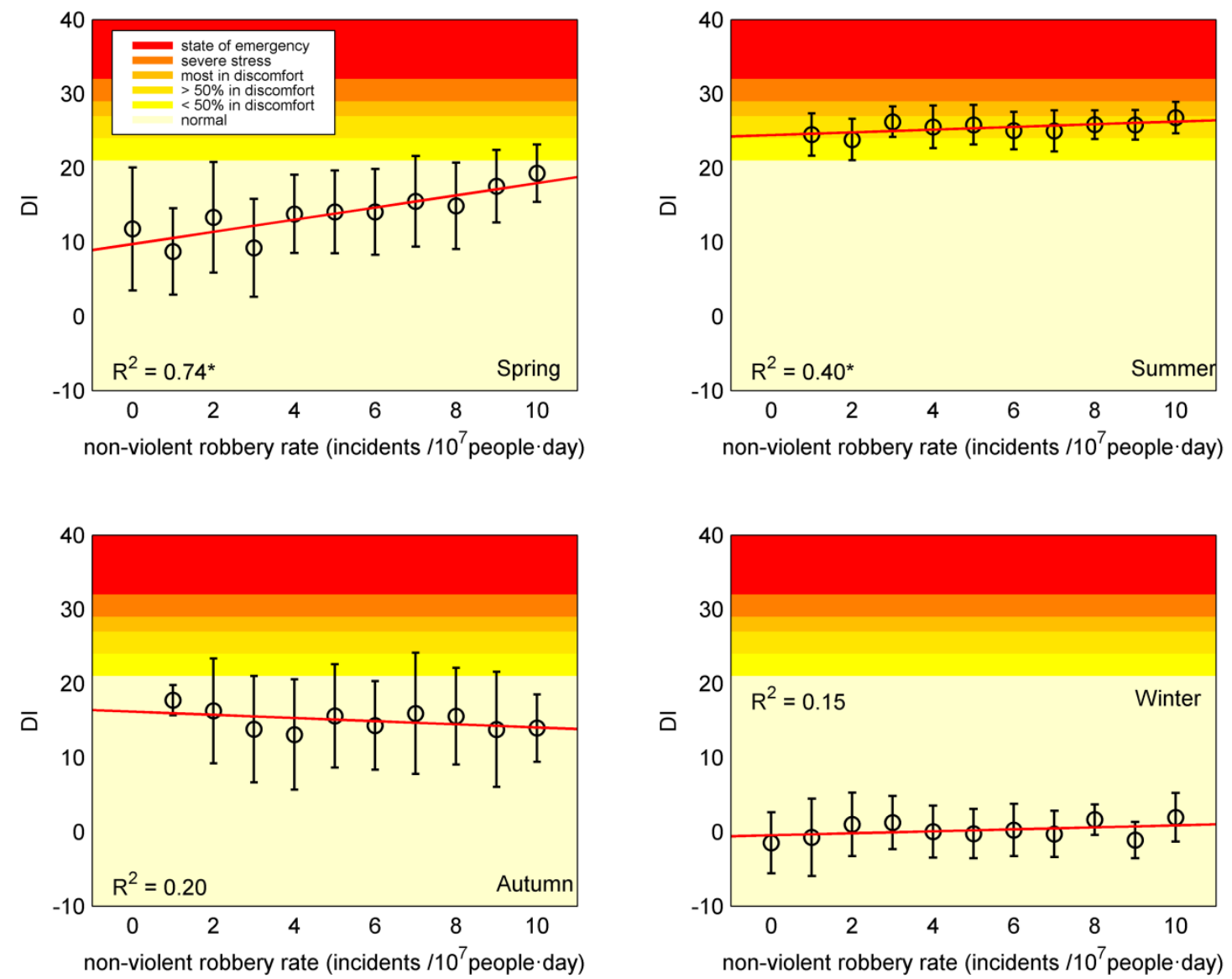

Fig. 4 The relation between non-violent robbery rates and DI values in Beijing before 2009. The red lines are fitted 

winter are lower than 0.2 and not significant.
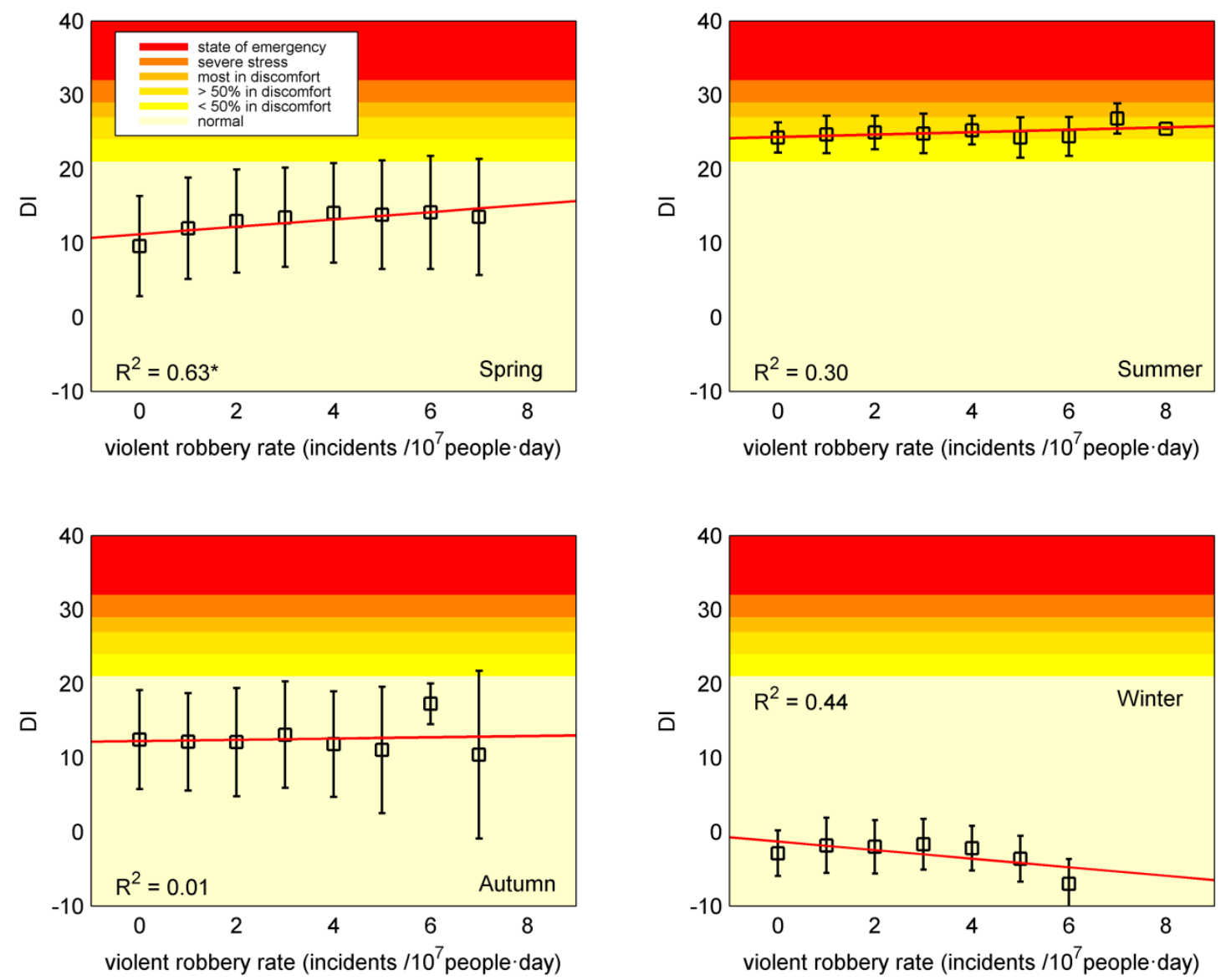

Fig. 5 The relation between violent robbery rates and DI values in Beijing after 2009. The red lines are fitted linear relations.

Fig. 5 shows the relation between violent robbery rates and DI values in different seasons after 2009. The violent robbery rate increases significantly with DI only in spring. In winter, although a decreasing trend is observed and the $\mathrm{R}^{2}$ value is larger than 0.4 , the relation is not 

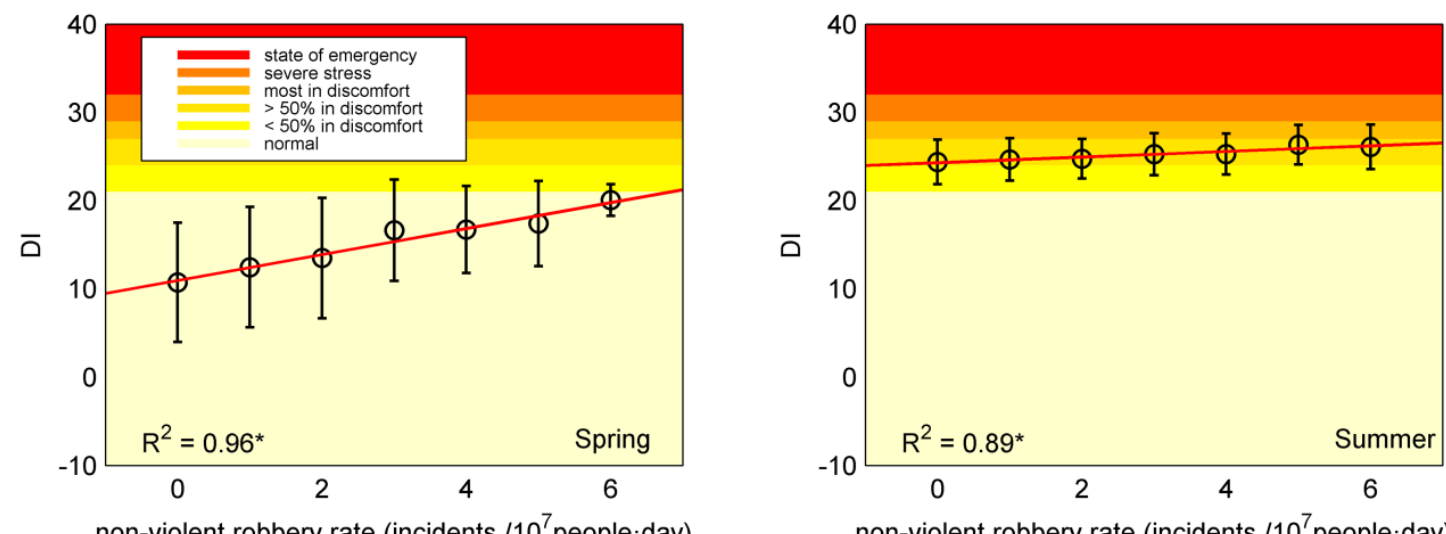

non-violent robbery rate (incidents $/ 10^{7}$ people $\cdot$ day)
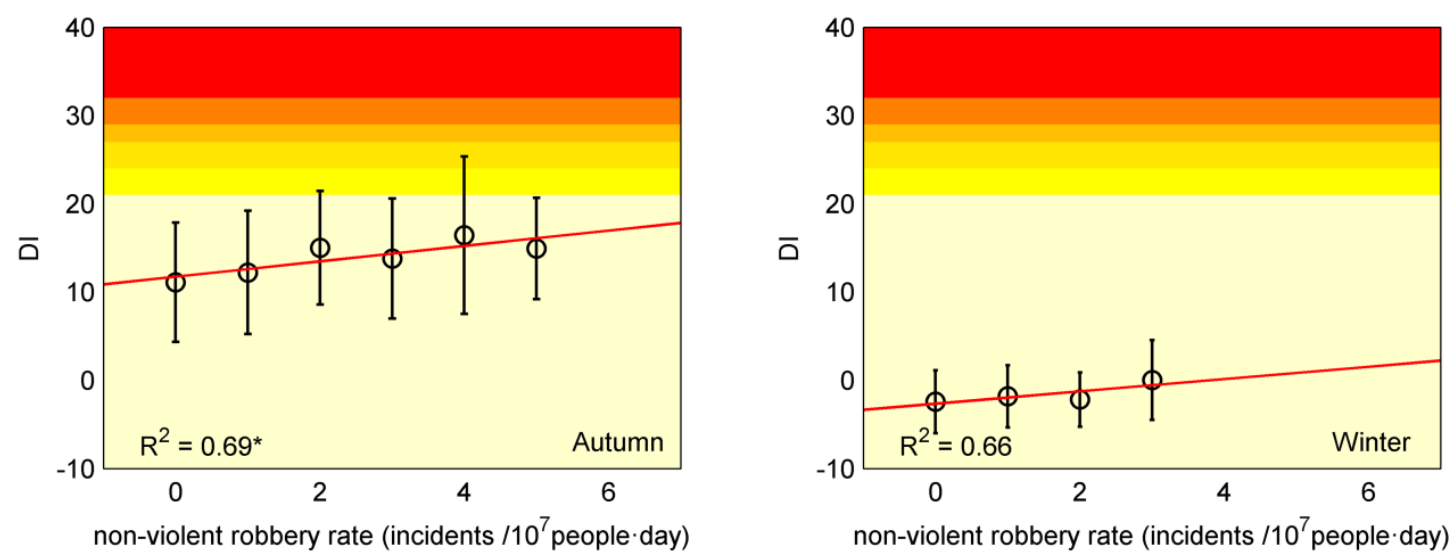

Fig. 6 The relation between non-violent robbery rates and DI values in Beijing after 2009. The red lines are fitted

linear relations.

Fig. 6 shows the relation between non-violent robbery rates and DI values in Beijing after 2009. It indicates that the non-violent robbery rates increase with DI values in all four seasons. Simple regression analysis shows that all $\mathrm{R}^{2}$ values in the four seasons are larger than 0.6 , and for spring and summer, the $\mathrm{R}^{2}$ values are even larger than or close to $0.9(\mathrm{p}<0.05)$, suggesting that non-violent robbery is strongly affected by heat stress across all four seasons after 2009 in Beijing. non-violent robbery rates significantly increase with heat stress in spring; 2) non-violent robbery rates also significantly increase with heat stress in summer; 3) in the period of 2009 to 2014 when 

robbery rates.

\subsection{The contrasting impacts of heat stress on violent and non-violent robbery}

Here we explore the reasons behind such differences between violent and non-violent robbery. Non-violent robbery is a essentially property crime which happens without violence, thus its relation with heat stress may be explained by the Routine Activity (RA) theory proposed by Cohen and Felson (1979). The RA theory points out that there are three necessary conditions for committing a crime: a likely offender, a suitable target, and the absence of a capable guardian.

Higher but not extreme heat stresses are more likely to increase mobility and social interaction thereby increasing the likelihood of a suitable target occurring and thus generating more opportunities for property crimes. The original RA theory, however, did not provide a clear significantly increase with heat stress in the DI ranges from "normal" to ">50\% discomfort". Under such heat stress conditions, the non-violent robbery rate generally increases with the HSI. literature, the General Affect (GA) model and the Negative Affect Escape (NAE) model were often used to explain the relation between temperature and violent crime. The GA model is similar to the RA model, which suggests that higher temperatures facilitate effective aggression (Cohn 
because of increases in discomfort, but only up to a certain point beyond which the relationship will be negative. As the discomfort increases over a threshold, the criminal's motivation to escape uncomfortable situations will eventually outweigh the motivation to be aggressive (Bell, 1992). Thus, an 'inverse-U-shaped' relationship should be observed between temperature and aggression. In summary, both GA and NAE models suggest a positive correlation between temperature and crime rate, but the NAE model further suggests a negative correlation when temperature is beyond a threshold. Our results seem to be more consistent with the GA model in the sense that 'inverse-U-shaped' relationship is not found. However, negative or no correlations are observed in Beijing, especially in the post-2009 period (see Fig. 5). As such, it is concluded that the relation between violent robbery and heat stress is more complex and less robust than the relation between non-violent robbery and heat stress; and neither GA nor NAE could fully explain such relations. 


\section{Conclusions}

This study investigates the influence of heat stress on two different types of robbery (violent vs. non-violent) using crime statistics and observed climate records in Beijing, China. Heat stress indices (DI, sWBGT, HUMIDEX, and THIC), which combine the effects of temperature and humidity on human comfort, are used in this paper. The results show that the abrupt change in the trends of robbery rates seems to be caused by the 2008 Beijing Olympic Games. As a result, it is assumed that the social and economic influence is responsible for the linear trend in robbery rates.

Correlations between both violent and non-violent robbery rates and heat stress at daily scales and

in different seasons are also examined. The most important conclusion is that both violent and non-violent robbery rates significantly increase with heat stress in spring. The non-violent robbery rates also significantly increase with heat stress in summer. In the period of 2009 to 2014 when no long-term trend can be detected, non-violent robbery rates are more strongly affected by heat stress than violent robbery rates. The results for non-violent robbery can be reasonably explained by the Routine Activity theory. However, the influence of heat stress on violent robbery is more factors such as heat stress have influences on crime rates, but they affect crime rates at different 2009 and after 2009) are broadly consistent, suggesting that the treatment of the influence of 
262 stress and crime rates is generally more robust in the second period when no linear trend exists.

263 Our study is a logical starting point given the data limitation but further investigations on

264 separating the influences of socio-economic factors and climatic factors are recommended. 


\section{Acknowledgements}

The authors appreciate support for this paper by the Collaborative Innovation Center of

267 Public Safety, the Basic scientific research project of People's Public Security University of China

268 (No. 2016JKF01211) and the National Science \& Technology Pillar Program during the 12th

269 Five-year Plan Period (No. 2015BAK12B03). This work was also supported by China Clean

270 Development Mechanism Foundation (No. 2013049). We are grateful to the Municipal Public

271 Safety Bureau of Beijing in China for proving the crime data.

272 


\section{References}

ACSM, 1984. Position stand on the prevention of thermal injuries during distance running. Medical Journal of Australia 141, 876-879.

Barnett, J., Adger, W.N., 2007. Climate change, human security and violent conflict. Polit Geogr $26,639-655$.

Bell, P.A., 1992. In defense of the negative affect escape model of heat and aggression. Psychological Bulletin 111, 342-346.

Bernauer, T., Bohmelt, T., Koubi, V., 2012. Environmental changes and violent conflict. Environ Res Lett 7.

Brunsdon, C., Corcoran, J., Higgs, G., Ware, A., 2009. The influence of weather on local geographical patterns of police calls for service. Environ Plann B 36, 906-926.

Burke, M.B., Miguel, E., Satyanath, S., Dykema, J.A., Lobell, D.B., 2009. Warming increases the risk of civil war in Africa. P Natl Acad Sci USA 106, 20670-20674.

Buzan, J.R., Oleson, K., Huber, M., 2015. Implementation and comparison of a suite of heat stress metrics within the Community Land Model version 4.5. Geosci Model Dev 8, 151-170.

Chen, P., Shu, X.M., Yuan, H.Y., Li, D.S., 2011. Assessing temporal and weather influences on property crime in Beijing, China. Crime Law Social Ch 55, 1-13.

Cohen, L.E., Felson, M., 1979. Social Change and Crime Rate Trends: A Routine Activity Approach. American Sociological Review 44, 588-608.

Cohn, E.G., Rotton, J., 2000. Weather, seasonal trends and property crimes in MINNEAPOLIS,1987-1988: a moderator-variable time-series analysis of routine activities. Journal of Environmental Psychology 20, 257-272. 
Field, S., 1992. The Effect of Temperature on Crime. British Journal of Criminology 32, 340-351.

Fischer, E.M., Oleson, K.W., Lawrence, D.M., 2012. Contrasting urban and rural heat stress responses to climate change. Geophys Res Lett 39.

Gamble, J.L., Hess, J.J., 2012. Temperature and Violent Crime in Dallas, Texas: Relationships and Implications of Climate Change. Western Journal of Emergency Medicine 8, 239-246.

Horrocks, J., Menclova, A., 2011. The effects of weather on crime. New Zealand Economic Papers $45,231-254$.

Hsiang, S.M., Burke, M., Miguel, E., 2013. Quantifying the Influence of Climate on Human Conflict. Science 341, 1212-+.

Hsiang, S.M., Meng, K.C., Cane, M.A., 2011. Civil conflicts are associated with the global climate. Nature 476, 438-441.

Ingram, D.L., 1965. Evaporative cooling in the pig. Nature 207, 415-416.

Jacob, B., Lefgren, L., Moretti, E., 2006. The Dynamics of Criminal Behavior: Evidence from Weather Shocks. Journal of Human Resources 42, 489-527.

Mares, D., 2013. Climate Change and Levels of Violence in Socially Disadvantaged Neighborhood Groups. J Urban Health 90, 768-783.

Masterson, J.M., Richardson, F.A., 1979. Humidex, a method of quantifying human discomfort due to excessive heat and humidity. Environment Canada, Atmospheric Environment Service, Downsview, Ontario, CLI.

Mehluma, H., Miguel, E., Torvik, R., 2006. Poverty and crime in 19th century Germany. Journal of Urban Economics 59, 370-388.

Miguel, E., 2005. Poverty and Witch Killing. The Review of Economic Studies 72, 1153-1172. 
O'Loughlin, J., Witmer, F.D.W., Linke, A.M., Laing, A., Gettelman, A., Dudhia, J., 2012. Climate variability and conflict risk in East Africa, 1990-2009. P Natl Acad Sci USA 109, 18344-18349.

Oleson, K.W., Monaghan, A., Wilhelmi, O., Barlage, M., Brunsell, N., Feddema, J., Hu, L., Steinhoff, D.F., 2015. Interactions between urbanization, heat stress, and climate change. Climatic Change 129, 525-541.

Ranson, M., 2014. Crime, weather, and climate change. J Environ Econ Manag 67, 274-302.

Scheffran, J., Brzoska, M., Kominek, J., Link, P.M., Schilling, J., 2012. Climate Change And Violent Conflict. Science 336, 869-871.

Steadman, R.G., 1984. A Universal Scale Of Apparent Temperature. J Clim Appl Meteorol 23, 1674-1687.

Thom, E.C., 1959. The discomfort index. Weatherwise 12, 57-61.

Tol, R.S.J., Wagner, S., 2010. Climate change and violent conflict in Europe over the last millennium. Climatic Change 99, 65-79.

Zhang, D.D., Lee, H.F., Wang, C., Li, B.S., Pei, Q., Zhang, J., An, Y.L., 2011. The causality analysis of climate change and large-scale human crisis. P Natl Acad Sci USA 108, 17296-17301. 


\section{Appendix}

The heat stress indices used in this paper are the Discomfort Index (DI), the simplified Wet

Bulb Globe Temperature (sWBGT), the Humidex (HUMIDEX) and the Temperature Humidity

Table A1 Heat stress indices

\begin{tabular}{|c|c|c|}
\hline Indices & Descriptions & References \\
\hline The discomfort Index (DI) & $\mathrm{DI}=0.5 T_{\mathrm{W}}+0.5 T_{\mathrm{C}}$ & Thom (1959) \\
\hline $\begin{array}{l}\text { The simplified Wet Bulb Globe Temperature } \\
\text { (sWBGT) }\end{array}$ & $\mathrm{sWBGT}=0.56 T_{\mathrm{C}}+\frac{0.393 e_{\mathrm{RH}}}{100}+3.94$ & $\operatorname{ACSM}(1984)$ \\
\hline The humidex (HUMIDEX) & $\mathrm{HUMIDEX}=T_{\mathrm{C}}+\frac{5}{9}\left(\frac{e_{\mathrm{RH}}}{100}-10\right)$ & $\begin{array}{l}\text { Masterson and } \\
\text { Richardson (1979) }\end{array}$ \\
\hline $\begin{array}{l}\text { The Temperature Humidity Index for Comfort } \\
\text { (THIC) }\end{array}$ & $\mathrm{THIC}=0.72 T_{\mathrm{W}}+0.72 T_{\mathrm{C}}+40.6$ & Ingram (1965) \\
\hline
\end{tabular}

$(\mathrm{Pa})$ is firstly calculated by:

$$
e_{\mathrm{RH}}=(\mathrm{RH} / 100) e_{s \mathrm{~Pa}}
$$

The saturated vapor pressure $e_{s \mathrm{~Pa}}$ is calculated using Magnus form approximation:

$$
e_{s \text { Pa }}=6.1078 \exp \left[\frac{17.13(T-273.16)}{T-38}\right] \times 100
$$

where $\mathrm{T}$ is the temperature in Kelvins. 
350 wet bulb temperature $T_{\mathrm{w}}\left({ }^{\circ} \mathrm{C}\right)$. Here, we use an approximation from (Oleson et al. (2015)) to

351 calculate the wet bulb temperature:

352

$$
\begin{aligned}
& T_{\mathrm{WS}}=T_{\mathrm{C}} \arctan (0.151977 \sqrt{\mathrm{RH}+8.313659})+\arctan \left(T_{\mathrm{C}}+\mathrm{RH}\right)-\arctan (\mathrm{RH}-1.676331) \\
& +0.00391838 \mathrm{RH}^{3 / 2} \arctan (0.023101 \mathrm{RH})-4.68035
\end{aligned}
$$

353

Table A2 Risk levels of different heat stress indices

\begin{tabular}{lll}
\hline SWBGT & HUMIDEX & THIC
\end{tabular}

Alert: $26.7-29.3$

Some discomfort: 30

Alert: 75

$<50 \%$ of population in

discomfort: $21-24$

Caution: $29.4-31.0$

Dangerous: 46

Dangerous: $79-83$

$>50 \%$ of population in

Discomfort: $24-27$

Potentially dangerous: Imminent heat stroke: 54 Very dangerous: $\geq 84$

Most of the population

$31.1-32.1$

in discomfort: $27-29$

Dangerous: $\geq 32.2$

Severe stress: $29-32$

State of emergency: $>32$ 